\title{
EFFECTS OF FUNGICIDE TREATMENT AND RHIZOBIUM INOCULATION ON CHEMICAL COMPOSITION OF FABA BEAN (Vicia faba L.) Seeds \\ Ahmed, T.H. M. ${ }^{*}$ and E. A. E. Elsheikh ${ }^{*}$ \\ * Faculty of Science an Technology,Shendi University. \\ ** Faculty of Agriculture, Khartoum University. \\ ${ }^{*}$ Corresponding author : tagelsir4m@gmail.com
}

\begin{abstract}
The effects of fungicidal seed dressing and Rhizobium inoculation on the chemical properties of faba bean seeds were studied. Two fungicides, Captan and Fernasan-D at concentrations between zero and $10 \mathrm{~g} / \mathrm{kg}$ seeds were used. Inoculation with Rhizobium leguminosorum bv. viceae strain TAL 1397 immediately before or after seed dressing or inoculation at the seedling stage was adopted.Compaired to uninoculated plants, Rhizobium inoculation by both methods significantly $(P \leq 0.01)$ increased seed moisture content, fat content, fibre and protein content. Carbohydrate content was significantly $(P \leq 0.01)$ decreased while no effect was detected on ash content. No clear differences were observed between inoculation immediately before or after seed dressing (First season). Fungicide seed dressing significantly $(P \leq 0.01)$ increased ash, moisture and carbohydrate contents when applied at the field recommended dose. Fat, fibre and protein contents were significantly $(P \leq 0.01)$ decreased with different degrees depending on fungicide toxicity and concentration. Increasing the concentration of both fungicides resulted in lower contents of fat, fibre and protein contents. No differences between the two fungicides were observed in the contents of moisture, ash and crude fibre. Captan seed dressing resulted in lower fat and crude protein content and higher carbohydrates content compared to Fernasan-D.
\end{abstract}

\section{INTRODUCTION}

Legumes are unique in the high protein content of their seeds and their ability to fix atmospheric nitrogen. Faba bean (Vicia faba L.) is one of the major leguminous crops in Africa as well as Sudan. It is mainly grown for human consumption. The popularity of faba bean may be due to its high protein content and availability at relatively reasonable price. It is considered as one of the main sources of cheap protein the protein content of faba bean ranges from 27 to $34 \%$ (Haciseferougullari, et al., 2003) Many efforts were directed to improve yield, protein content, and cookability and to decrease tannins and hard seed percentage of legumes seeds through breeding, fertilization and/or genetic engineering. Biofertilization receives a great attention because of its minimal effect on the environment and its longer lasting effect. Many factors act upon legume - Rhizobium symbiosis and may positively or negatively affect the yield and seed quality. These factors include cultivar, agricultural practices and locality or environment (Elsheikh and Elzidany, 1997). Rhizobium inoculation of faba bean has been found to increase yield and improve seed quality (Mohamed Ahmed and Abdalla,2004). Chemical and biological fertilizers were reported to increase protein content of faba bean (Babiker et al., 1995). Fungicidal seed dressing 
is one of the factors that interfere with legume- Rhizobium association and affect chemical and physical properties of the seeds.

Objectives of this study was to assess the effects of fungicide treatment and the method of Rhizobium inoculation on protein content and proximate composition of faba bean seeds, variety "Agabat".

\section{MATERIALS AND METHODS}

Two field experiments were conducted during two cropping seasons in the Demonstration Farm of the Faculty of Agriculture at Shambat (Latitude $15: 40 / \mathrm{N}$, Longitude $32: 32 / \mathrm{E}$ ), to study the effects of fungicidal seed dressing and Rhizobium inoculation on chemical composition of faba bean seeds. Table (1) shows some chemical and physical properties of the soil. The land was prepared by deep ploughing, harrowing and leveling. The area was then ridged and divided into $4 \times 4 \mathrm{~m}$ plots, $80 \mathrm{~cm}$ between ridges and 5 north - south ridges per plot.

Seeds of faba bean cultivar Agabat were purchased from commercial sources from Shendi. Rhizobium leguminesarum by viceae strain TAL 1397 was supplied by the Environment and National Resources Institute (ENNRI),National Research Council, Sudan. The Crop Protection Department, Ministry of Agriculture, Khartoum North, supplied the fungicides Captan and Fernasan -D.

\section{Treatments Used:}

Captan or Fernasan - D treatment at concentration of:

Zero $\mathrm{g} / \mathrm{kg}$ seeds as control

$2 \mathrm{~g} / \mathrm{kg}$ seeds, $4 \mathrm{~g} / \mathrm{kg}$ seeds, $6 \mathrm{~g} / \mathrm{kg}$ seeds, in the first season and increased to $8 \mathrm{~g} / \mathrm{kg}$ seeds and $10 \mathrm{~g} / \mathrm{kg}$ seeds in the second season.

Table (1): Some chemical and physical properties of Shambat soil

\begin{tabular}{|c|c|c|c|c|c|c|c|c|c|c|}
\hline \multicolumn{2}{|c|}{$\begin{array}{c}\text { Particle size } \\
\text { distribution \% }\end{array}$} & pH & $\begin{array}{c}\text { Ec } \\
\text { (ds/m) }\end{array}$ & \multicolumn{5}{|c|}{ Soluble Cations } & SAR(meq/l) & $\begin{array}{c}\text { Total N } \\
\%\end{array}$ \\
\hline sand & silt & Clay & & & K & Na & Ca & Mg & & \\
\hline 18 & 17 & 65 & 8.2 & 1.2 & 0.26 & 10.83 & 4.25 & 1.21 & 4.43 & 0.064 \\
\hline
\end{tabular}

In the first season, each of these treatments was either inoculated immediately before or after fungicidal seed dressing or at the seedling stage in the furrow or otherwise uninoculated. No differences were observed between inoculation immediately before or after seed dressing .Only inoculation in conjunction with fungicidal seed dressing was adopted in the second season. Five disinfected seeds were sown per hole thinned to three at the seedling stag. The crop was irrigated every $10-15$ days. The experiments were arranged in a complete randomized block design with three replicates.At harvest, the seeds were carefully cleaned, then ground to passs a $0.4 \mathrm{~mm}$ screen for proximate analysis.

AOAC (1984) methods were followed in the determination of moisture, crude fibre, crude protein and fat content. Carbohydrates content was determined by differences. 


\section{Statistical Analysis:}

Each sample was analyzed in triplicates and figures were then averaged. Data were assessed by analysis of variance (ANOVA) (Snedecor and Cochran,1987) with the probability of $p \leq 0.01$.

\section{RESULTS AND DISCUSSION}

\section{Moisture content:}

As shown in Table (2), results of the first season indicated that moisture content is not affected by any of the treatments. In the second season (Table 3) Rhizobium inoculation significantly $(p \leq 0.01$ ) increased seed moisture content over the uninoculated control plants. The increment in moisture content of faba bean seeds due to Rhizobium inoculation was reported by Elsheikh and Elzidany, (1997). Fungicidal seed dressing by Captan or Fernasan - D significantly $(p \leq 0.01)$ increased moisture content over the control plants up to the recommended dose but decreased again with increasing dose up to $10 \mathrm{~g} / \mathrm{kg}$ seeds. The moisture content of faba bean seeds was found to be in the range of 3.7 to $5.7 \%$. Values reported before were 6.6 - 7.8\%, (Elsheikh and Elzidany 1997) and 4-6\% (Ahmed, 1998).

Generally, the moisture content of legume seed was found to be affected by the relative humidity during storage (Elsayed, 1994).

Table (2): Effects of fungicides treatment and Rhizobium inoculation on moisture and ash content of faba bean seeds.(first season).

\begin{tabular}{|c|c|c|c|c|c|}
\hline \multirow{2}{*}{$\begin{array}{c}\text { Concentration } \\
\text { g/kg seed }\end{array}$} & \multirow{2}{*}{$\begin{array}{l}\text { Rhizobium } \\
\text { inoculation }\end{array}$} & \multicolumn{2}{|c|}{ Moisture content (\%) } & \multicolumn{2}{|c|}{ Ash content(\%) } \\
\hline & & Fernasan-D & Captan & Fernasan-D & Captan \\
\hline \multirow[t]{4}{*}{0} & R0 & $4.15( \pm 0.07)$ & $4.31( \pm 0.15)$ & $2.9( \pm 0.4)$ & $2.5( \pm 0.4)$ \\
\hline & $\mathrm{R} 1$ & $3.93(+0.11)$ & $4.18(+0.04)$ & $3.1(+0.3)$ & $2.3(+0.6)$ \\
\hline & $\mathrm{R} 2$ & $4.13(+0.11)$ & $4.16( \pm 0.06)$ & $3.0( \pm 0.1)$ & $2.8( \pm 0.6)$ \\
\hline & R3 & $3.68( \pm 0.60)$ & $4.10( \pm 0.07)$ & $3.2( \pm 0.3)$ & $2.5( \pm 0.5)$ \\
\hline \multirow[t]{4}{*}{2} & R0 & $3.99( \pm 0.01)$ & $3.64( \pm 0.79)$ & $3.5( \pm 0.1)$ & $3.0( \pm 0.1)$ \\
\hline & R1 & $3.85( \pm 0.01)$ & $4.11( \pm 0.13)$ & $3.4( \pm 0.4)$ & $3.1( \pm 0.3)$ \\
\hline & $\mathrm{R} 2$ & $4.10( \pm 0.14$ & $4.25( \pm 0.01)$ & $3.5( \pm 0.4)$ & $2.9( \pm 0.3)$ \\
\hline & R3 & $4.15(+0.07)$ & $4.13( \pm 0.14)$ & $3.1( \pm 0.1)$ & $2.5( \pm 0.5)$ \\
\hline \multirow[t]{4}{*}{4} & R0 & $3.95(+0.07)$ & $3.90( \pm 0.14)$ & $2.9( \pm 0.6)$ & $2.5( \pm 0.5)$ \\
\hline & R1 & $4.08(+0.11)$ & $4.11( \pm 0.06)$ & $3.5( \pm 0.5)$ & $2.9( \pm 0.5)$ \\
\hline & $\mathrm{R} 2$ & $4.03( \pm 0.11)$ & $4.08( \pm 0.04)$ & $3.4( \pm 0.5)$ & $3.0( \pm 0.4)$ \\
\hline & R3 & $4.04(+0.09)$ & $4.16( \pm 0.06)$ & $3.5( \pm 0.6)$ & $3.1( \pm 0.1)$ \\
\hline \multirow[t]{4}{*}{6} & R0 & $4.00(+0.02)$ & $4.17( \pm 0.06)$ & $3.1( \pm 0.4)$ & $2.8( \pm 0.2)$ \\
\hline & R1 & $4.10(+0.07)$ & $4.11( \pm 0.13)$ & $3.0( \pm 0.1)$ & $3.5( \pm 0.1)$ \\
\hline & $\mathrm{R} 2$ & $4.06(+0.07)$ & $4.19( \pm 0.05)$ & $2.8( \pm 0.6)$ & $3.0( \pm 0.1)$ \\
\hline & R3 & $4.15( \pm 0.07)$ & $3.99(+0.16)$ & $3.0(+0.1)$ & $3.4( \pm 0.4)$ \\
\hline
\end{tabular}

$\begin{array}{lcc} & \text { Moisture content (\%) } & \text { Ash content (\%) } \\ \text { LSD for Fungicide (F) } & \text { NS } & \pm 0.155 \\ \text { LSD for Dose (D) } & \text { NS } & \pm 0.219 \\ \text { LSD for Inoculation (I) } & \text { NS } & \text { NS } \\ \text { LSD for F } \times \text { D } & \text { NS } & \pm 0.310 \\ \text { LSD for F } \times \text { I } & \text { NS } & \text { NS } \\ \text { LSD for D } \times \text { I } & \text { NS } & \text { NS } \\ \text { LSD for F } \times \text { D } \times \text { I } & \text { NS } & \text { NS }\end{array}$

Ro $=$ Control.

$\mathbf{R} 1$ = Seed inoculation immediately before seed dressing.

$\mathbf{R} 2$ = Seedling inoculation immediately after seed dressing.

R3 = Seedling inoculation. 


\section{Ash conten:}

Rhizobium inoculation by either method did not affect ash content of faba bean seeds (Tables 2 and 3). Fungicide seed dressing significantly ( $p \leq$ 0.01 ) increased ash content of the seeds compared to untreated control plants. Fernasan-D treatments resulted in higher ash content compared to Captan. Increasing the concentration of either fungicide from zero to the field recommended dose increased ash content by $2 \%$,where increasing the concentration to $10 \mathrm{gm}$ fungicide/ $\mathrm{Kg}$ seeds decreased the percentage of ash content by $2.4 \%$ but lower than the control plants. Similar findings were reported with fenugreek (Abdelgani, 1997).

The ash content of foodstuff represents the residue remaining after the organic matter has burnt. The ash obtained is not necessarily of exactly the same composition as the mineral matter present in the original food as there may be losses due to volatilization or as a result of some interactions between constituents.

Table (3): Effects of fungicides treatment and Rhizobium inoculation on moisture and ash content of faba bean seeds.(second season).

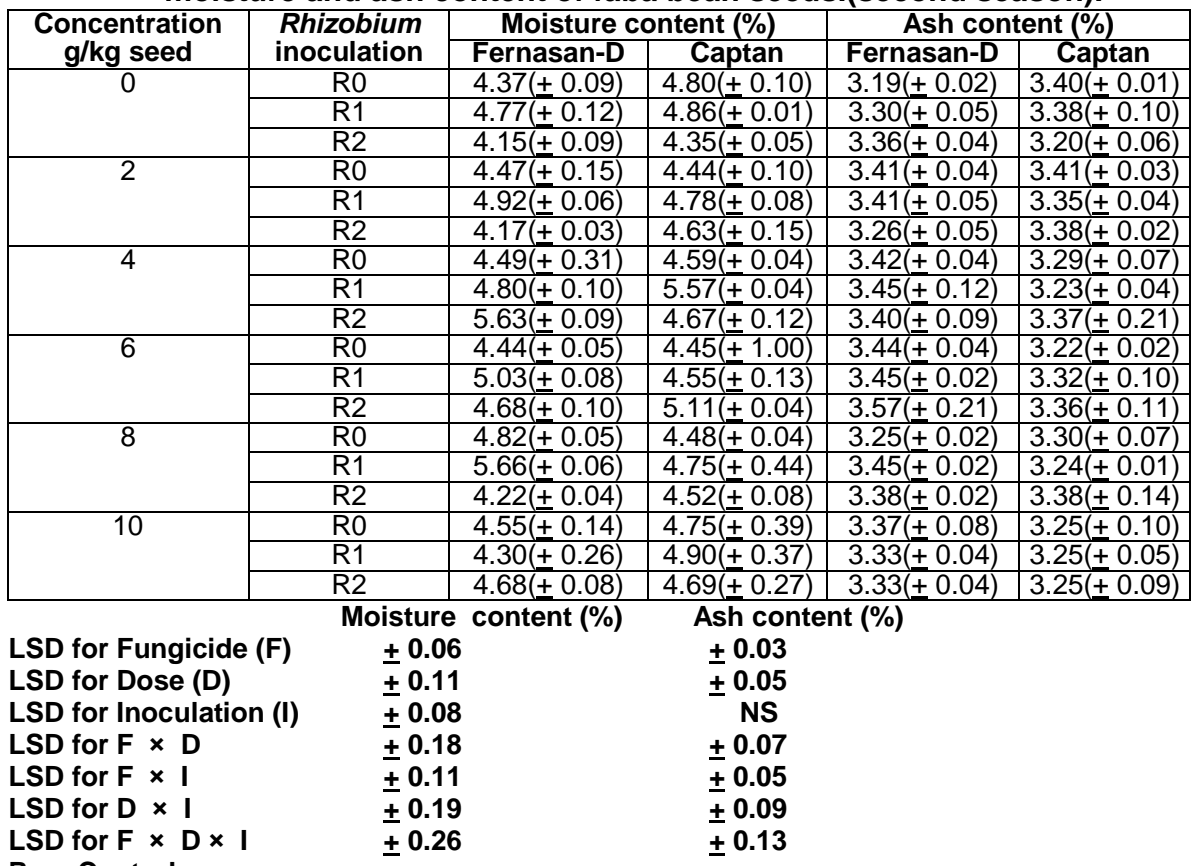

Ro $=$ Control

R1 = Seed inoculation

R2= Seedling inoculation

Fat content:

As shown in Tables (4 and 5), Rhizobium inoculation significantly ( $p$ $\leq 0.01$ ) increased fat content of faba bean seeds. Seedling inoculation resulted in higher fat content compared to seed inoculation. Fungicide seed dressing significantly $(p \leq 0.01)$ decreased it with different degrees depending on the fungicide toxicity. Captan, which is more toxic, resulted in lower fat 
content than Fernasan-D. Increasing the fungicide concentration above the recommended dose significantly $(p \leq 0.01)$ decreased faba bean seeds fat content.

Table (4): Effects of fungicides treatment and Rhizobium inoculation on

\begin{tabular}{|c|c|c|c|c|c|}
\hline \multirow{2}{*}{$\begin{array}{l}\text { Concentration } \\
\text { g/kg seed }\end{array}$} & \multirow{2}{*}{$\begin{array}{l}\text { Rhizobium } \\
\text { inoculation }\end{array}$} & \multicolumn{2}{|c|}{ Fat content (\%) } & \multicolumn{2}{|c|}{ Crude fibre content (\%) } \\
\hline & & Fernasan-D & Captan & Fernasan-D & Captan \\
\hline \multirow[t]{4}{*}{0} & R0 & $1.47( \pm 0.31)$ & $1.13(+0.15)$ & $5.8( \pm 0.7)$ & $6.7( \pm 0.2)$ \\
\hline & R1 & $1.20( \pm 0.20)$ & $1.23( \pm 0.12)$ & $6.8( \pm 0.3)$ & $6.9( \pm 0.4)$ \\
\hline & $\mathrm{R} 2$ & $1.83(+0.33)$ & $1.27(+0.31)$ & $6.5( \pm 0.4)$ & $6.9(+0.3)$ \\
\hline & R3 & $1.77(+0.15)$ & $1.23(+0.25)$ & $6.7( \pm 0.3)$ & $6.8( \pm 0.2)$ \\
\hline \multirow[t]{4}{*}{2} & R0 & $1.07( \pm 0.12)$ & $1.20( \pm 0.01)$ & $7.1( \pm 0.4)$ & $6.5( \pm 0.2)$ \\
\hline & R1 & $1.16( \pm 0.12)$ & $1.30( \pm 0.20)$ & $7.2( \pm 0.4)$ & $7.1( \pm 0.2)$ \\
\hline & $\mathrm{R} 2$ & $1.47( \pm 0.25)$ & $0.90( \pm 0.50)$ & $7.0( \pm 0.1)$ & $7.0( \pm 0.1)$ \\
\hline & R3 & $1.87( \pm 0.15)$ & $1.20( \pm 0.17)$ & $5.9( \pm 0.5)$ & $7.0( \pm 0.1)$ \\
\hline \multirow[t]{4}{*}{4} & R0 & $1.10( \pm 0.17)$ & $1.07(+0.15)$ & $6.5( \pm 0.4)$ & $6.6(+0.1)$ \\
\hline & R1 & $1.10(+1.70)$ & $1.10( \pm 0.40)$ & $6.9( \pm 0.4)$ & $6.0( \pm 0.1)$ \\
\hline & $\mathrm{R} 2$ & $1.37( \pm 0.15)$ & $1.00( \pm 0.01)$ & $6.8( \pm 0.3)$ & $5.8( \pm 0.4)$ \\
\hline & R3 & $1.43( \pm 0.12)$ & $1.33( \pm 0.15)$ & $6.8( \pm 0.4)$ & $5.6( \pm 0 .)^{3}$ \\
\hline \multirow[t]{4}{*}{6} & R0 & $1.00( \pm 0.01)$ & $0.93(+0.12)$ & $6.2( \pm 0.2)$ & $6.7( \pm 0.3)$ \\
\hline & R1 & $1.27( \pm 0.25)$ & $1.27( \pm 0.05)$ & $6.8( \pm 0.2)$ & $6.9( \pm 0.3)$ \\
\hline & $\mathrm{R} 2$ & $1.33( \pm 0.25)$ & $1.07( \pm 0.21)$ & $6.6( \pm 0.2)$ & $6.8( \pm 0.1)$ \\
\hline & R3 & $1.37( \pm 0.05)$ & $1.30( \pm 0.01)$ & $6.5( \pm 0.2)$ & $6.9( \pm 0.3)$ \\
\hline
\end{tabular}

LSD for Fungicide (F)

LSD for Dose (D)

LSD for Inoculation (I)

LSD for $F \times D$

LSD for $F \times 1$

LSD for $D \times 1$

LSD for $F \times D \times$ I

Ro $=$ Control.

R1 = Seed inoculation immediately before seed dressing

$\mathbf{R} 2$ = Seedling inoculation immediately after seed dressing.

R3 = Seedling inoculation.

The increase in fat content of faba bean seeds due to biological fertilization was reported by Elsheikh and Elzidany, (1997), groundnut and fenugreek, (Abdelgani,1997). Fat content of faba bean was found to be in the range of $0.9-1.8 \%$ which was comparable to previous values were $1.6-2 \%$ ( Musallam, et al., 2004).

Crude Fibre Content:

Rhizobium inoculation by either method significantly $(p \leq 0.01)$ increased crude fibre content of faba seeds over the control uninoculated plants. Fungicidal seed dressing at doses above the field recommended rates significantly $(p \leq 0.01)$ decreased fibre content whereas no significant differences were observed between the two fungicides (Tables 4 and 5).

Regardless the treatment applied the crud fiber content of faba bean seeds found to be in the range of 5.6-7.2\% . Reported values were $5.7-6.78 \%$ (Elsheikh and Elzidany, 1997).

In general, the crude fibre content is influenced by the environmental condition and varietal characteristics. In faba bean, the cultivar, location and time of harvest are the factors that led to fibre content variation (EL Tinay et al.,1989). 
Table (5): Effects of fungicides treatment and Rhizobium inoculation on fat and crude fibre content of faba bean seeds.( second season).

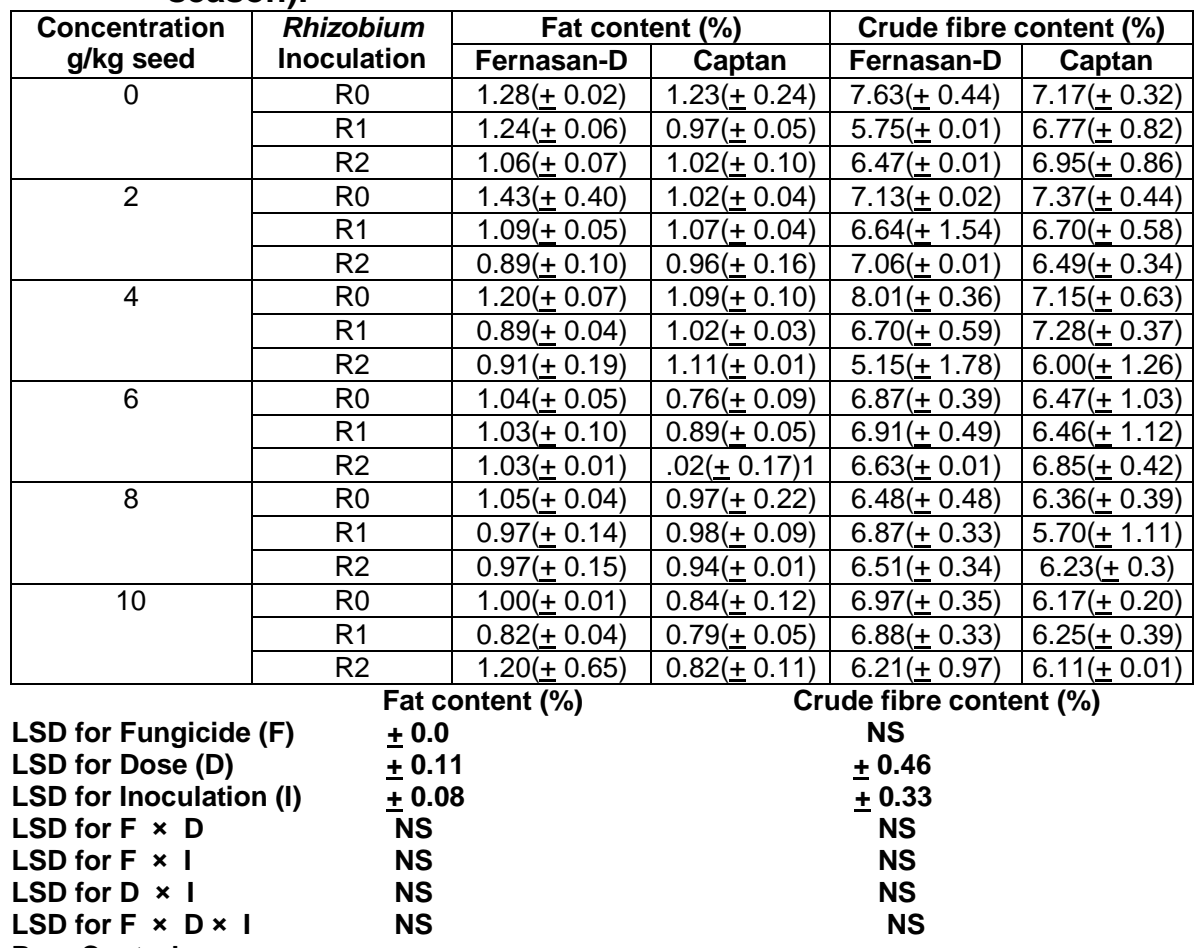

Ro $=$ Control

R1 = Seed inoculation

R2= Seedling inoculation

\section{Crude Protein Content:}

Legume seeds are rich in protein. The crude protein content in the seeds varied from $31.8 \%$ to $39.7 \%$ (Alghamdi,2009) with a well-balanced amino acid pattern. Faba bean contains a high protein content compared to other legumes seeds which amount to $33.4 \%$ ( Elsheikh et al.,2000).

Rhizobium inoculation significantly $(\mathrm{p} \leq 0.01)$ increased crude protein content of faba bean seeds over the uninoculated control plants by $7 \%$. Seedling inoculation resulted in higher values than seed inoculation (Tables 6 and 7). El Tilib et al. (1994) reported that protein content increases with improved plant nutrition and that Rhizobium inoculation and nitrogen fertilization were found to increase protein content of faba bean (Babiker et al., 1995), and indeed other legumes such as soybean (Mukhtar and Abu Naib, 1988).

Fungicidal seed dressing significantly $(p \leq 0.01)$ decreased crude protein content of the seeds. The amount of reduction was proportional to the fungicide toxicity and concentration as toxicity and high concentrations reduced the efficiency of nitrogen fixation (Abdelgani,1997). Captan was found to reduce crude protein of faba bean seeds by $20 \%$ compared to $19 \%$ reduction by Fernasan-D. 


\section{Carbohydrates content:}

Rhizobium inoculation significantly $(\mathrm{p} \leq 0.01)$ decreased carbohydrates content compared to uninoculated control plants (Tables 6 and 7). The amount of carbohydrates ranged between 47.85 and $57.3 \%$.Reported values ranged between 52.2 and $60.5 \%$ (Musallam et al,.2004)The results reflect the effect of inoculation on moisture, fat, fibre and protein contents where the increase in these constituents due to inoculation was countered by decrease in carbohydrates content The reduction in carbohydrates content of faba bean seeds due to Rhizobium inoculation was reported by Elsheikh and Elzidany, (1997). Fungicidal seed dressing by both fungicide significantly ( $p$ $\leq$ 0.01) increased the carbohydrates content. Increasing the fungicide concentration over the recommended field rate also resulted in a significant $(p \leq 0.01)$ increase in this parameter (Abdelgani,1997).

Generally, the carbohydrate content is inversely related to the protein content of faba bean seeds (Elsheikh and Elzidany, 1997).

Table (6): Effects of fungicides treatment and Rhizobium inoculation on crude protein and carbohydrates content of faba bean seeds. (first season)

\begin{tabular}{|c|c|c|c|c|c|}
\hline \multirow{2}{*}{$\begin{array}{l}\text { Concentration } \\
\text { g/kg seed }\end{array}$} & \multirow{2}{*}{$\begin{array}{l}\text { Rhizobium } \\
\text { inoculation }\end{array}$} & \multicolumn{2}{|c|}{$\begin{array}{c}\text { crude protein content } \\
(\%)\end{array}$} & \multicolumn{2}{|c|}{ carbohydrates content (\%) } \\
\hline & & Fernasan-D & Captan & Fernasan-D & Captan \\
\hline \multirow[t]{4}{*}{0} & R0 & $33.97( \pm 0.21)$ & $31.90( \pm 1.70)$ & $51.68( \pm 0.8)$ & $53.49( \pm 0.4)$ \\
\hline & $\mathrm{R} 1$ & $34.23( \pm 0.65)$ & $32.90( \pm 1.20)$ & $50.74( \pm 0.7)$ & $52.79( \pm 0.8)$ \\
\hline & $\mathrm{R} 2$ & $34.57( \pm 0.59)$ & $33.00( \pm 0.01)$ & $49.97( \pm 0.3)$ & $51.87( \pm 1.0)$ \\
\hline & R3 & $36.33( \pm 1.52)$ & $35.40( \pm 0.50)$ & $48.32( \pm 1.7)$ & $49.97( \pm 0.8)$ \\
\hline \multirow[t]{4}{*}{2} & R0 & $32.70( \pm 020)$. & $31.00(+0.90)$ & $51.64( \pm 0.0)$ & $54.69( \pm 0.8)$. \\
\hline & $\mathrm{R} 1$ & $32.47( \pm 0.32)$ & $32.40( \pm 0.80)$ & $51.91( \pm 0.4)$ & $51.99( \pm 1.1)$ \\
\hline & $\mathrm{R} 2$ & $32.70( \pm 0.60)$ & $32.80( \pm 0.70)$ & $51.23( \pm 0.4)$ & $47.85( \pm 0.7)$ \\
\hline & R3 & $34.87(+0.31)$ & $34.20(+0.80)$ & $50.11(+0.1)$ & $50.97(+0.7)$ \\
\hline \multirow[t]{4}{*}{4} & R0 & $31.47( \pm 0.42)$ & $30.80( \pm 0.80)$ & $53.18( \pm 0.8)$ & $55.13( \pm 1.5)$ \\
\hline & $\mathrm{R} 1$ & $31.70( \pm 0.30)$ & $32.20( \pm 0.80)$ & $52.72( \pm 0.9)$ & $53.69( \pm 0.8)$ \\
\hline & $\mathrm{R} 2$ & $31.20( \pm 0.30)$ & $31.70( \pm 0.60)$ & $53.20( \pm 0.3)$ & $54.42( \pm 0.7)$ \\
\hline & R3 & $33.60( \pm 0.30)$ & $34.00( \pm 0.01)$ & $50.60( \pm 0.1)$ & $51.98( \pm 0.8)$ \\
\hline \multirow[t]{4}{*}{6} & R0 & $29.90( \pm 0.40)$ & $28.27( \pm 0.80)$ & $55.80( \pm 0.8)$ & $57.30( \pm 0.6)$ \\
\hline & $\mathrm{R} 1$ & $31.10( \pm 0.01)$ & $30.13( \pm 0.57)$ & $53.76( \pm 0.9)$ & $54.10( \pm 0.4)$ \\
\hline & $\mathrm{R} 2$ & $30.80( \pm 0.40)$ & $29.80( \pm 0.78)$ & $54.41( \pm 0.7)$ & $55.16( \pm 0.2)$ \\
\hline & R3 & $33.83( \pm 0.35)$ & $33.07( \pm 0.21)$ & $51.18( \pm 1.1)$ & $51.24( \pm 0.8)$ \\
\hline $\begin{array}{l}\text { SD for Fungicio } \\
\text { SD for Dose (D) } \\
\text { SD for Inoculat } \\
\text { SD for } F \times D \\
\text { SD for } F \times 1 \\
\text { SD for } D \times I \\
\text { SD for } F \times D \times\end{array}$ & (F) & $\begin{array}{l}\text { ude protein cc } \\
.28 \\
.40 \\
.40 \\
.57 \\
.57 \\
\text { IS } \\
\text { S }\end{array}$ & itent (\%) & $\begin{array}{r}\text { Carbohydra } \\
\pm 0.33 \\
\pm 0.47 \\
\pm 0.47 \\
\pm 0.66 \\
\pm 0.66 \\
\pm 0.94 \\
\pm 1.33\end{array}$ & es (\%) \\
\hline
\end{tabular}

R1 = Seed inoculation immediately before seed dressing.

R2 = Seedling inoculation immediately after seed dressing.

R3 = Seedling inoculation . 
Table 7: Effects of fungicides treatment and Rhizobium inoculation on crude protein and carbohydrates content of faba bean seeds. (second season).

\begin{tabular}{|c|c|c|c|c|c|}
\hline \multirow{2}{*}{$\begin{array}{c}\text { Concentration } \\
\text { g/kg seed }\end{array}$} & \multirow{2}{*}{$\begin{array}{c}\text { Rhizobium } \\
\text { Inoculation }\end{array}$} & \multicolumn{2}{|c|}{ crude protein content } & \multicolumn{2}{|c|}{ carbohydrates content } \\
\hline & & Fernasan-D & Captan & Fernasan-D & Captan \\
\hline \multirow[t]{3}{*}{0} & R0 & 33.93( 00.42) & $31.50( \pm 1.72)$ & $49.60( \pm 0.71)$ & $52.41( \pm 1.04)$ \\
\hline & R1 & $34.80( \pm 0.20)$ & $32.21( \pm 1.85)$ & $50.14( \pm 1.27)$ & $51.81( \pm 0.37)$ \\
\hline & $\mathrm{R} 2$ & $35.60( \pm 0.53)$ & $33.55( \pm 1.37)$ & $49.36( \pm 1.27)$ & $50.92( \pm 0.37)$ \\
\hline \multirow[t]{3}{*}{2} & R0 & $32.80( \pm 0.36)$ & $32.60( \pm 0.40)$ & $50.70( \pm 0.21)$ & $51.16( \pm 0.45)$ \\
\hline & R1 & $33.33( \pm 0.32)$ & $34.60( \pm 1.40)$ & $50.91( \pm 0.09)$ & $49.50( \pm 0.88)$ \\
\hline & $\mathrm{R} 2$ & $34.93( \pm 0.21)$ & $35.10( \pm 2.30)$ & $49.66( \pm 1.18)$ & $49.44( \pm 0.88)$ \\
\hline \multirow[t]{3}{*}{4} & R0 & $31.70( \pm 1.30)$ & $33.40( \pm 1.70)$ & $51.18( \pm 0.37)$ & $50.48( \pm 0.36)$ \\
\hline & R1 & $32.90( \pm 1.00)$ & $34.60( \pm 1.80)$ & $51.08( \pm 0.27)$ & $48.30( \pm 0.73)$ \\
\hline & $\mathrm{R} 2$ & $33.40( \pm 0.40)$ & $35.00( \pm 0.01)$ & $51.51( \pm 0.36)$ & $49.85( \pm 1.00)$ \\
\hline \multirow[t]{3}{*}{6} & R0 & $30.40( \pm 1.20)$ & $31.20( \pm 0.50)$ & $53.81( \pm 0.36)$ & $52.91( \pm 0.28)$ \\
\hline & $\mathrm{R} 1$ & $29.97( \pm 1.15)$ & $31.60( \pm 0.90)$ & $53.61( \pm 0.45)$ & $53.16( \pm 0.37)$ \\
\hline & $\mathrm{R} 2$ & $32.17( \pm 0.50)$ & $32.90( \pm 0.50)$ & $51.92( \pm 1.00)$ & $50.76( \pm 0.20)$ \\
\hline \multirow[t]{3}{*}{8} & R0 & $31.30( \pm 1.36)$ & $29.00( \pm 0.01)$ & $53.10( \pm 1.10)$ & $55.89( \pm 1.08)$ \\
\hline & R1 & $31.57( \pm 0.86)$ & $31.00( \pm 0.01)$ & $52.48( \pm 0.64)$ & $54.33( \pm 0.82)$ \\
\hline & $\mathrm{R} 2$ & $32.67( \pm 0.26)$ & $32.40( \pm 1.10)$ & $52.37( \pm 0.64)$ & $52.53( \pm 0.82)$ \\
\hline \multirow[t]{3}{*}{10} & R0 & $29.40( \pm 1.24)$ & $27.90( \pm 0.90)$ & $54.70( \pm 0.79)$ & $57.09( \pm 0.18)$ \\
\hline & $\mathrm{R} 1$ & $30.70( \pm 1.21)$ & $29.53( \pm 0.61)$ & $53.93( \pm 0.90)$ & $55.38( \pm 0.62)$ \\
\hline & $\mathrm{R} 2$ & $32.53( \pm 0.50)$ & $31.17( \pm 0.37)$ & $53.05( \pm 0.86)$ & $54.94( \pm 0.73)$ \\
\hline
\end{tabular}

LSD for Fungicide (F)

LSD for Dose (D)

LSD for Inoculation (I)

LSD for $F \times D$

LSD for $F \times 1$

LSD for $D \times 1$

LSD for $F \times D \times$ I

Ro $=$ Control

R1 = Seed inoculation

R2= Seedling inoculation
Crude protein content (\%) Carbohydrates (\%)

$\begin{array}{lc} \pm 0.36 & \pm 0.30 \\ \pm 0.62 & \pm 0.51 \\ \pm 0.44 & \pm 0.36 \\ \pm 0.88 & \pm 0.72 \\ \text { NS } & \pm 0.51 \\ \text { NS } & \pm 0.51 \\ \text { NS } & \text { NS }\end{array}$

\section{REFERENCES}

Abdelgani, M.E.(1997).Effect of Rhizobium on nitrogen fixation, yield and seed quality of Fenugreek(Trigonella foenugraeeum L).PhD Thesis, Faculty of Agriculture, University of Khartoum.

Ahmed, E.I.A.(1998). Effect of intercropping and inoculation with Rhizobium on growth, Yield and seed quality of faba bean. M.Sc.(Agric.) Thesis, University of Khartoum.

Alghamdi,S. Salem (2009). Chemical composition of faba bean seeds (Vicia faba L.) genotypes under various water regimes. Pakistan Journal of Nutrition.vol.9 (4),477-482.

AOAC (1984). Official Methods of Analysis Association of Official Analytical Chemists. AOAC. Washington,DC.USA.

Babiker ,E.E.; Elsheikh, E. A. E., Osman, A.G. and El Tinay, A.H.(1995). Effect of nitrogen fertilization and viral infection on yield, tannin and

Protein content and nitrogen fertilization and viral infection on yield, tannin and protein content and in vitro protein digestibility of faba bean. Plant Foods for Human Nutrition 47: 257-263. 
Elsayed M.E.(1994). The influence of locality and genotype on quality aspects of faba bean (Vicia faba L.)cultivars. M.Sc. (Agric.)Thesis, University of Khartoum.

Elsheikh ,E.A.E. and Elzidany,A.A.(1997). Effect of Rhizobium inoculation, organic and chemical Fertilizers on proximate composition, in vitro protein digestibility, tannin and sulpher content of faba bean. Food chemistry 59(1),41-45.

Elsheikh ,E.A.E EITinay, A.H. and Fadual,I.A.(2000).Effect of nutritional status of faba bean on proximate composition, anti- nutritional factors and in vitro protein digestibility(IVPD). Food chemistry 68: 211-212.

El Tilib, A.M.A.,Ali, A.M., and Abdallah,M.A.(1994)Effect of chicken manure and salinity on growth and leaf $\mathrm{N}, \mathrm{P}$ and $\mathrm{K}$ content of okra grown on two soil types. University of Khartoum Journal of Agricultural Science.,2:16-33

Haciseferougullari, H.; Gezer,I.;Bahtiyarca,Y. and Menges, H.O. (2003). Determination of some chemical and physical properties of Sakiz bean (Vicia faba L.var. major). Journal of Food Engineering,vol. 60(4): 475479.

Mohamed Ahmed, T.H. and Abdalla,A.S.,(2004). The Response of Some Legumes to Rhizobium Inoculation and the Effect of NPK Fertilizer on Their Symbiosis. Shendi University Journal, Issue NO. 1,62-81.

Mukhtar, N.O. and Abu Naib, S.A.(1988).biological nitrogen fixation by faba bean , lentil and chickpea. In the traditional versus the new areas of the Sudan. In Nitrogen.

Musallam, I.W.; Karaki, G.N.; Ereifei, K.I.; Rahman, A. and Tawaha, A.R.M. (2004). Chemical composition of faba bean genotypes under rainfed and irrigation condition .International Journal of Agriculture and Biology. Vol.6(2),359-362.

Snedecor, G. W. and Cochran, W. G. (1987). Statistical Methods $7^{\text {th }}$ Ed, Amed, IA. The Lowa State University Press. Pp $221-222$. 
تأثير المبيدات الفطريـة والتلقيح ببكتريـا العقد الجذريـة على الخصـائص الكيميائيـة لبذور الفول المصري (البلدي) تاج البر حسن محمد أحمد 1 و و الصديق الصدي أحمد المصطفى الشيخ 2

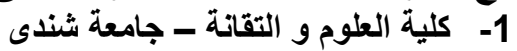

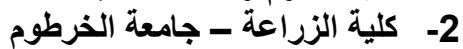

${ }^{*}$ Corresponding author : tagelsir4m@gmail.com

تمت دراسة تأثثير المبيدات الفطرية والتلقيح ببكتريا العقد الجذرية على الخصـائص

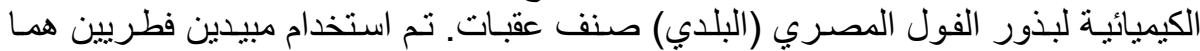

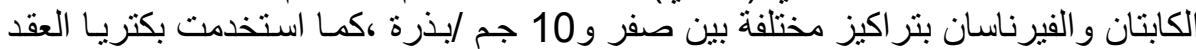

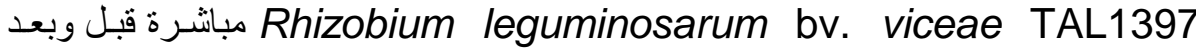
إضافة المبيد الفطري للبذرة أو عند ظهور البادرات.

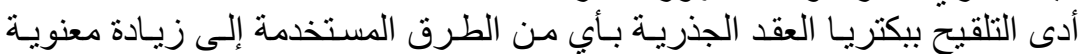
(PS0.01)

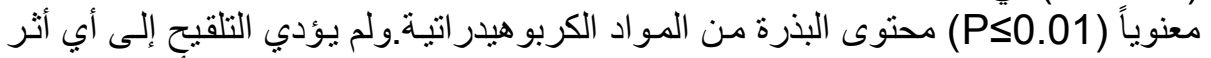

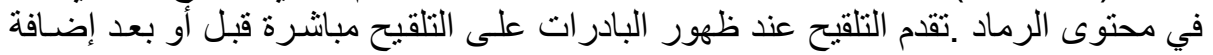
المبيد الفطري في كل المعادمالات تحت الدر استة.

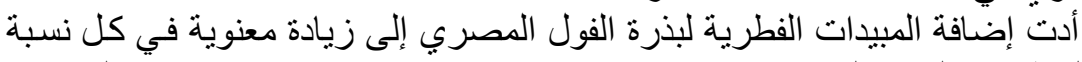

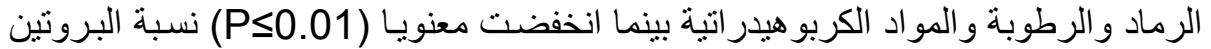

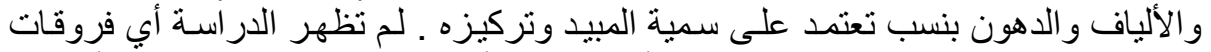

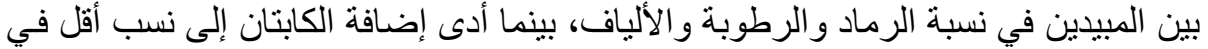

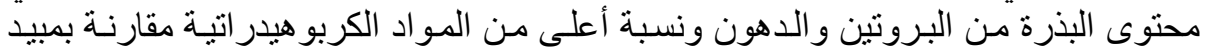

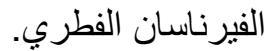

كلية الزراعة - جامعة المنصورة

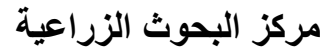

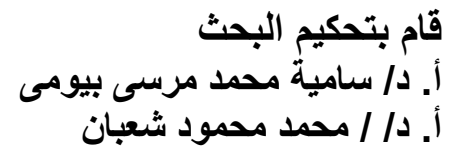

